\title{
NEW URBAN DEMANDS IN EARLY MODERN LONDON
}

\author{
Rosemary Weinstein
}

From 1550 onwards, London grew and changed enormously, with the attendant problems of disease and disorder. The combined impact of "rapid immigration, recurrent mortality crises and population growth applied critical pressures to the social and administrative structures" of the metropolis. " This paper gives an overview of how local authorities endeavoured to deal with problems of drainage, water supply, and street cleaning between 1500 and 1700 .

Despite London's growth in area and population, it continued to have two separate administrative centres - the Court of Common Council in the City, and from 1585 the Court of Burgesses at Westminster. Outside the City liberties and Westminster, the Middlesex Justices of the Peace (the royal representatives) were responsible, either collectively or as individuals, for law and order. This division led to conflict over public responsibilities. The City, for example, could not compel the Middlesex Justices to clear the Fleet River above Holborn Bridge of the filth which polluted the downstream City ward of Farringdon Without. No single authority ran hospitals and almshouses, organized street cleaning or policed streets in the new suburbs east and west of the City-Stepney, Soho, and St James's. "Many problems of drainage and flood prevention, safe building, welfare, fire prevention, medical care and education were outside the powers of the Justices of the Peace and the parish vestries to control. Various ad hoc bodies were set up to deal with these problems", 2 as we shall see.

The Corporation of London has a tradition extending back to the Middle Ages of care for the health of the citizens. The City archives contain many references, from the thirteenth century on, to ordinances dealing with water supplies, the adulteration of food, the cleansing of streets, the removal of refuse and the abatement of the grosser nuisances, including smoke, and the provision of hospitals for the sick poor. ${ }^{3}$ Such measures for the promotion of public health were mainly organized on a ward basis

Mrs Rosemary Weinstein, Keeper, Tudor and Stuart Department, Museum of London, London Wall, London EC2Y 5HN

ACKNOWLEDGEMENTS

I wish to thank the staff of the Corporation of London Record Office, and Mr G. C. Berry, former archivist to the Metropolitan Water Board, for information and advice.

\footnotetext{
${ }^{1}$ P. Clark and P. Slack, English towns in transition 1500-1700, Oxford University Press, 1976, 94.

2 Inner London Education Authority (ILEA), The growth of London, sixteenth century: beginning of expansion, London, ILEA Media Resources Centre, 1974.

${ }^{3}$ Corporation of London Record Office (CLRO), Misc. MSS 311.15; and Betty R. Masters, The City of London and clean air 1273-1973, London, Corporation of London, 1973.
} 
under the authority of the Alderman, and carried out and supervised by such ward-appointed officers as rakers, scavengers, beadles, and constables. "Nuisances" were presented at the wardmotes (inquests). Much depended on the co-operation of the inhabitants, particularly where the cleansing and lighting of the streets were concerned. ${ }^{4}$

Ad hoc bodies for particular undertakings such as commissions of drains (that is, for surplus water, not sewage in the modern sense) and sewers were set up from time to time, at least from the reign of Edward I (r. 1272-1307). In 1449, the Aldermen and Recorder were commissioners for the sewer known as Turnmill Brook (Fleet Sewer), and from Elizabeth I's reign there was a more-or-less permanent Commission of ten members nominated by the Court of Aldermen and appointed by the Crown. All these early commissioners had power to tax the houses benefiting by their improvements. $^{5}$

Commissioners of Sewers for Surrey and Kent were appointed in 1554, after bad floods in 1530 and a subsequent Bill of Sewers in 1531; their court minutes survive from 1569. ${ }^{6}$ These commissioners covered the area south of the Thames from East Molesey in Surrey to the River Ravensbourne in Kent. As well as sewers for surface drainage, the commissioners maintained the Thames river wall to prevent the central portion of the area being submerged by any unusually high tides. Recorded in the court minutes are "presentments" (objections) concerning repairs to sewers. Juries with the power to fine offending parties were appointed to go around and inspect the sewers to see that they were being maintained. ${ }^{7}$

Among the useful schemes carried out by the commissioners for Holborn and Finsbury was the draining in 1606 of Moorfields, north of the City wall, to become the country's first civic park, and the construction of the large London Bridge sewer, which ran across the City partly on the line of the Walbrook, and discharged at London Bridge. They also had many streams and ditches filled in. ${ }^{8}$

The Court Minutes of the Commission for the Sewers relating to Westminster go back to 1659; they deal, in the main, with the protection of river navigation and the preservation of the district from flooding. Little business appears in the records for the first year, 1659, although they do include an order to the inhabitants of the new development of Bedford Street, Covent Garden, to clean their sewer. ${ }^{9}$

${ }^{4}$ CLRO, Misc. MSS 11.25.

5 Ibid.

${ }^{6}$ ILEA, op. cit., note 2 above; and Greater London Record Office (GLRO) SKCS 18. Sewers were for conveyance of surplus water to the Thames. Until 1815, it was a penal offence to discharge household or cesspool waste into the sewers; it was then permissible to drain houses into sewers, and in 1847 this was made compulsory.

${ }^{7}$ GLRO, Court Minutes of the Surrey and Kent Sewer Commission, vol. 1: ed. G. L. Gomme, London, LCC, 1909, vii. Ida Darlington, The London Commissioners of Sewers and their records, Chichester, Phillimore, 1970.

${ }^{8}$ Sir George W. Humphreys, Main drainage of London, London, LCC, 1930, 7, 9. In 1974, excavations by the Museum of London at Seal House (west of Fishmongers' Hall) on the City waterfront, revealed a drain probably of sixteenth-century date running towards the Thames. The contents were examined for dietary information. David Crossley, Post-medieval archaeology in Britain, Leicester University Press, 1990, 96; and John Cherry (ed.), 'Post-medieval Britain in 1975: Section 3-Towns and corporate buildings', $J$. Society for Post-Medieval Archaeology, 1976, 10: 163, 4.

${ }^{9}$ N. G. Brett-James, The growth of Stuart London, London, Allen \& Unwin, 1935, 137, 139; and GLRO, Westminster Commission of Sewers (WCS) 37. Holborn and Finsbury Commission of Sewers (HFCS). 
In 1662 an Act of Parliament gave the Commissioners power not only to make sewers and vaults but also to repair, pave and cleanse the highways, to supervise ward scavengers, and to widen streets. This short-lived Act covered the Cities of London and Westminster, Poplar, and the outer districts in Surrey and Kent. These commissioners were arbitrary Crown appointments.

By the Act of 1671 following the Great Fire, a permanent body of Commissioners of Sewers was set up in the City of London, with appointments in the hands of the Mayor, Aldermen, and Common Council. This representative body had powers "to impose any reasonable tax upon all houses within the said City and the Liberties thereof". Thus representation and the burden of paying City rates for City purposes came together for the first time; subsequent municipal legislation developed on this principle. ${ }^{10}$ The rates for the purpose of carrying out the Commissioners' improvements were assessed on a ward basis.

Probably the most continuous day-to-day concern for citizens of London and Westminster, representing the most immediate threat to health and hygiene, was the removal of refuse and the suppression of nuisances of various types, including smoke and noise. Although the enactments that followed the Plague and Great Fire are often seen as the first municipal legislation and the origin of health services in the City, in 1654 the Common Council had already attempted a central organization for cleaning the streets and removing house refuse, when it entered into a contract with one John Lanyon to undertake with his own carts and workmen the duties formerly carried out by some 400 ward-appointed scavengers and rakers. After the Great Fire, the Commissioners also attempted to use the general contract system, but largely owing to lack of co-operation by the inhabitants, it proved unworkable. In 1683, ward contracts were introduced, and the ward-elected scavengers became rate-collectors. ${ }^{11}$

${ }^{10}$ W. G. Bell, The Great Fire of London, London, Bodley Head, 1920, ch. 14.

${ }^{11}$ CLRO, Misc. MSS 11.25, Proposals of John Lanyon for a Contract (1654):

It is too apparent that notwithstanding many persons and considerable sums of money are employed for cleansing the streets yet they grow daily more offensive with dust and unwholesome stenches in summer and in wet weather with dirt, which occasions a swarm of Coaches, to the disturbance of the City and the increase of noisome soil that whereof being by rain washed into the common sewers and passages and thence into the Thames, the sewers are much obstructed, the common passages, particularly Holborn Ditch formerly of great conveniency now rendered useless and the greatest annonyancy in the City and the River itself, especially above Bridge, made daily less navigable. Besides the Avenues to the City are almost all day pestered with those Carts which only carry away some small part of the soil out of the streets and are made exceeding noisome and almost impassable with dirt carelessly spilt by the way to the common Laystalls, which being many and so near the City yield a great and contagious stench, offensive to passengers but especially to the skirts of the Town, which else would be the most delightful places, and what wind so ever blows brings those noisome vapours into the City itself, sometimes to increase if no the beginning of infection.

The scavengers being yearly chosen contract with the rakers and give not thought except in what time they can spare from their business to collect the rate and pay it to the rakers and hope not to lose no more than $£ 510.0$. The rakers being insufficiently paid employ their carts from time to time on more profitable jobs and are not under any general superintendence.

He proposed that one person be made responsible under penalty, that an order be made that coal ash and house sweeping were not collected by the carts daily, and that householders should be obliged, as anciently to sweep the streets before their doors. 


\section{Rosemary Weinstein}

The danger of industrial pollution was noted as early as 1371 , when citizens living in Candelwykestrete (Cannon Street) and St Clement's Lane, Eastcheap, reported to the Mayor, Recorder, and Alderman, that two plumbers were using a vacant piece of ground in the neighbourhood for the melting of solder "to the great damage and peril of death of all who shall smell the smoke from such melting", for "whosoever has smelt the smoke therefrom has never escaped without mischief". ${ }^{12}$ The remedy for obnoxious fumes from permanent workshops was frequently to raise the chimney high enough to clear the smoke above the house-tops.

As early as 1299 , ordinary sea-coal (that is, coal from Newcastle transported by sea) was recognized as dangerous to health, since it gave off large quantities of sulphurous smoke when burned. Certain master smiths agreed not to work at night because of inconvenience caused to their neighbours, and by royal proclamation in 1307 the use of sea-coal was forbidden in kilns in Southwark, Wapping, and East Smithfield. In 1578, Elizabeth I was "greatly grieved and annoyed by the taste and smoke of the sea-coles", from brewhouses near Westminster Palace, whereupon the Brewers' Company offered to burn wood instead. In 1595, one Thomas Owen proposed to transport smokeless coal and anthracite to London from South Wales in order to help rid the metropolis of smoke. None of the attempts to replace sea-coal as a fuel was successful, and by 1600 its use was general in the houses of the upper classes, owing to the increasing scarcity of wood. ${ }^{13}$

The most scathing attack against the dangers of pollution from smoke and fumes to health, works of art, and general domestic comfort, came from John Evelyn, in his Fumifugium, or the smoke of London dissipated (1661), who wrote that,

though a chamber be never so closely locked up, men found at their return, all things that are in it, even covered with a black thin soot and all the rest of the furniture as full of it as it were in the house of some miller, or a baker shop where the flour gets into their cupboards and boxes ... Almost one half of them perished in London die of phthisical and pulmonic distempers. The inhabitants are never free from coughs and importunate rheumatisms, spitting of impostumated and corrupt matter.

Evelyn further commented that the gardens about London no longer bore fruit: for example, orchards in the Barbican and the Strand, which had been observed to have a good crop in 1654, when Newcastle was besieged and only a small quantity of coal was brought to London, now had difficulty in getting the trees even to bear leaves, let alone fruit. Evelyn's remedy was to remove the smoke-making establishments to at least six miles down the Thames, whilst Timothy Nourse, in his $A$ discourse on the fuel of London (1700), proposed a grandiose scheme for reafforestation within twenty to

Mr Lanyon proposed that he, with his own men and carts should perform the duties formerly carried out by 500 scavengers and rakers, who previously changed every year, in consideration of the present sum collected in the precincts (ward sub divisions) for scavage, together with money raised by sale of the soil, on condition that he was given a long lease.

1245 Edward III AD 1371. CLRO, Letter Book G, f.cclxxiii. Cited in H. T. Riley, Memorials of London and London life, London, 1868, 355; and Masters, op. cit., note 3 above, [n.p.].

${ }^{13}$ Arnold Marsh, Smoke: the problem of coal and the atmosphere, London, Faber, 1947, 22, 23. 


\section{New urban demands in early modern London}

thirty miles of London, even at the expense of arable land. ${ }^{14}$ The increasing pollution from industrial and domestic chimneys was not halted until 1956 with the City of London's Clean Air Act.

Whilst the problems of drainage, water supply, and nuisance affected all parts of the metropolis, attempts at control were divided between the City, the City and Borough of Westminster, and the Middlesex Justices of the Peace. Since in Westminster, the ecclesiastical authorities, the Vestry, and the Manor Courts were not able to deal with all the problems of nuisance, in 1585 Lord Burghley, as High Steward and Chief Secretary, persuaded Parliament to pass an Act enabling him to carry out the required reforms. He established a new Court of Burgesses that lasted until 1901. Under this administration Westminster was divided into twelve wards, each with a Burgess and an assistant. These unpaid officials were to follow the example of the Aldermen's deputies in the City of London. It was not intended that the Court of Burgesses should be as independent as the Court of Common Council in the City, nor that a Burgess should have the power of an Alderman. The Burgesses were required to report within twenty-four hours any lawbreaking activity including common nuisances, to a Justice or Justice of the Peace for the Court of Middlesex. ${ }^{15}$

To help the Court of Burgesses deal with the many nuisances, a special Commission for Annoyances was set up in 1581 under a private 'Act for the good government of the City and Borough of Westminster in Middlesex' (23 Eliz.). Its powers were wide and included the prohibition of divided tenements and other undesirable buildings, the closure of brothels, and the provision of street cleaning. A similar commission was set up in Holborn, and other parts of Middlesex.

A particular problem for the county's inhabitants was the repair of highways, for which every freeholder had to provide men or wagons for so many days, according to the proportion laid down by the Justices. Paving was a task imposed upon some parishioners. As in the City of London, a raker, who in Westminster was a parish, not a ward official, was responsible for seeing that the streets were kept clean and that drains and ditches were properly scoured.

Judging from the many "presentments" delivered to the Court of Burgesses and Justices of the Peace, and the rules and enforcements made, the authorities could hardly "be charged with indifference to the health of Westminster and its suburbs, and [they] acted within the customs, the standards and the limits of knowledge of the times". ${ }^{16}$ These, however, were the obvious nuisances: greater perils lay in the crowded burial grounds within the walls, poisoned springs of water, the cesspits near every dwelling, whose sewage was only cleared by the night-carts to laystalls in St Martin-in-the-Fields and other outlying areas, and the general insufficiency of food among the poorer people.

The Webbs' study shows that, between 1720 and 1756, the power of the Court of Burgesses greatly diminished, there having grown up in the late seventeenth century

\footnotetext{
14 Ibid, 25, 27.

${ }^{15}$ Brett-James, op. cit., note 9 above, 131-2. W. H. Manchée, The Westminster City Fathers 1585-1909, London, Bodley Head, 1929, ch. 2, 5-11.

${ }^{16}$ GLRO, John E. Jeaffreson (ed.), Middlesex County Records, vol. 3: 1615-16, 1974, xv-xxiii. Laystalls (i.e., depositories), inter alia for the sweepings from the streets, the refuse and ashes from the houses, and the oils, dirt and dung from inns, stables and places of trade.
} 


\section{Rosemary Weinstein}

the powerful Close Vestries and the Westminster Commission of the Peace; by these rivals for the government of Westminster, Burghley's "Makeshift" was gradually suppressed. Its power for making by-laws, for example, became practically disused (the reason given being that the inhabitants refused to comply with its ordinances, and the lack of a fund to support the expense of the Court enforcing their observances. $^{17}$

As mentioned above, in 1662 an Act of Parliament (confirmed by others in 1670, 1690, and 1697) had empowered, above all, special Commissioners and then the Justices, to enforce the householder's obligation to pave and cleanse in front of his house down to the gutter. By the early eighteenth century, therefore, the Justices were dealing with exactly the same kind of nuisances as the Court of Burgesses had for the past hundred years. The latter, however, retained its authority over watch and ward, and, for example, policed the new parishes of St Anne, Soho (created in 1678) and St James, Westminster (1685). ${ }^{18}$

The sources of water in the early-Stuart City of London were barely an improvement on those in the medieval City: the Thames, with its dual purpose as water supply and sewer, and wells like Holywell, "much decayed and marred with filthiness", Clerkenwell, and Goswell (figure 1). Since 1285, a pipeline had run from Tyburn Springs to a public outlet in Cheapside. Other piped systems followed, but by 1600 there were still fewer than twenty public taps in the City. Water was valuable, and anyone carrying a weapon was forbidden to approach these outlets.

Westminster was supplied from the Thames, the King's conduit in Palace Yard, the conduit at Knightbridge, and various springs and ordinary wells. Major new supplies within our period were largely confined to the Covent Garden development and the new squares. The responsibility for supplying water to the City of London rested with the Corporation, which was occasionally assisted by the charitable bequests of wealthy citizens. Certain religious bodies, such as the Charterhouse, had also had their own conduit system since the fifteenth century. Recent archaeological work at Clerkenwell showed that the Clerk's Well was enlarged in the seventeenth and eighteenth centuries as the water-table fell. ${ }^{19}$

Peter Morritz erected a water-wheel under the first arch at London Bridge in 1581 . He has the distinction of being the first to provide a supply of water up to Leadenhall and Old Fish Street by mechanical means, in the form of a force-pump. By 1800, the London Bridge waterworks, as they had become known, were reported to supply four million gallons of water daily. The great fall of water that they occasioned endangered navigation through the Bridge, and the waterworks were removed by an Act of Parliament in 1822 , but with the proviso that the duties to supply water were to be conveyed to the New River Company. The Metropolitan Water Board, as successor to the New River Company, paid annuities in respect of this early venture amounting

${ }^{17}$ S. and B. Webb, English local government, vol. 2, bk. 3: The manor and the borough, London, 1908, 215.

18 Ibid., 216.

${ }^{19}$ In 1674, the well was given to the parish by the Earl of Northampton. G. Egan (ed.), 'Post-medieval Britain in 1982: Section 3-Towns and corporate buildings', J. Society for Post-Medieval Archaeology, 1983, 191, 2; cited in Crossley, op. cit., note 8 above, 96. 


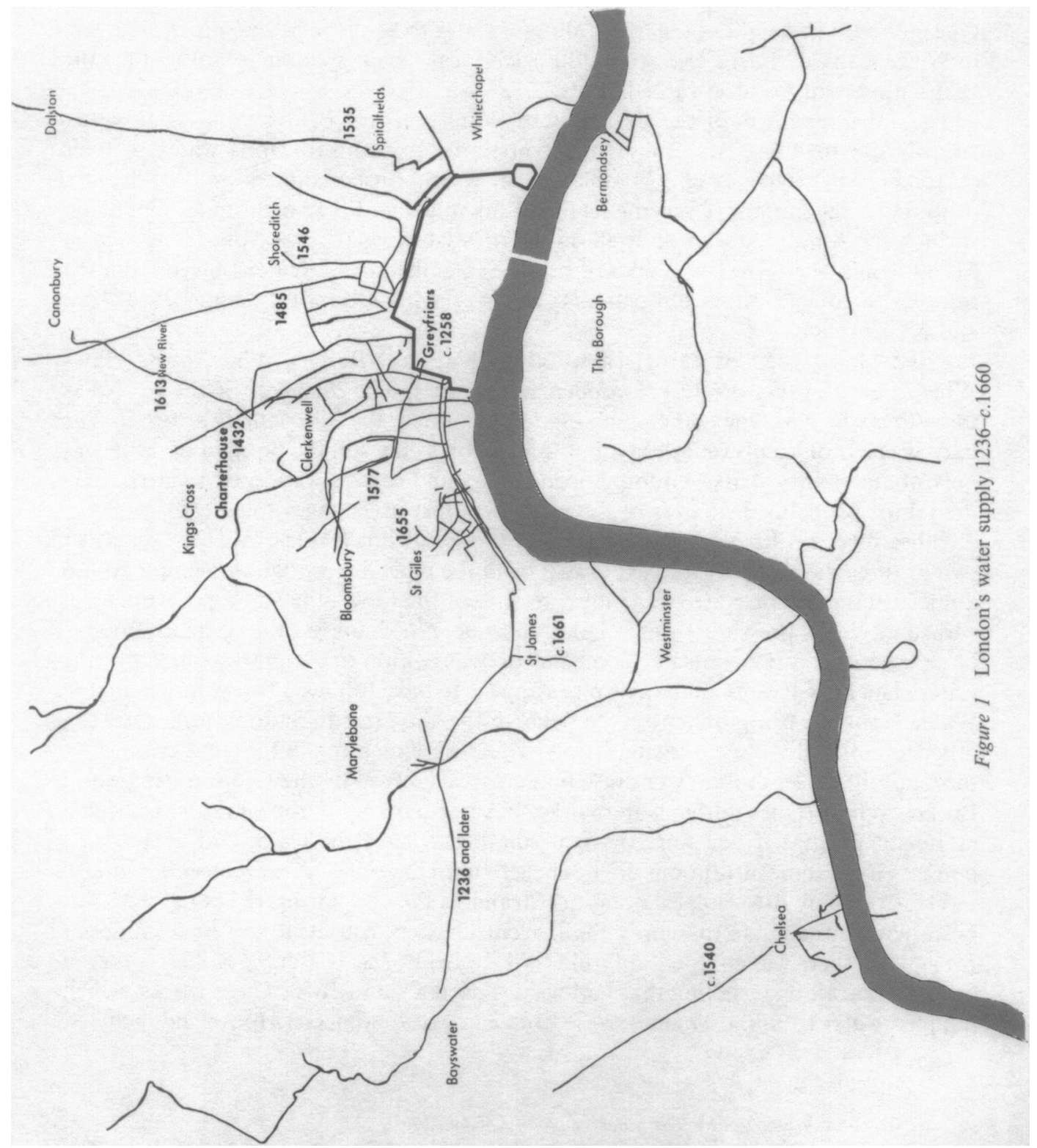




\section{Rosemary Weinstein}

to $£ 3,750$ per annum, and the Thames Water Authority will continue to do so until the year $2082 .{ }^{20}$

In 1593, the City lent Bevis Bulmer $£ 1,000$ to assemble a pump and water-tower at Queenhithe. The height of the tower allowed water to be taken in lead pipes to houses in Westcheap and East Fleet Street. But such local schemes could do nothing for the vast majority of London's inhabitants.

The 4,000 members of the Company of Water-tankard Bearers, who took water from house to house, naturally fought attempts to bring in piped water to their customers. In 1609, Hugh Myddleton, a Welsh business man and goldsmith, proposed a revolutionary scheme. He built an aqueduct thirty-eight miles long from springs at Amwell and Chadwell in Hertfordshire to a reservoir in Islington. Myddleton's New River was opened on 29 September 1613. Water flowed from the reservoir through hollow elm trunks to clients paying a quarterly rent, between $5 s$. and $6 s .8 d$ (plate 1).

From about 1650 or earlier, a wood-yard at Pipe-Borer's Wharf (now Hay's Wharf), Southwark, produced wooden water-pipes. The diameter of the bore was three to six inches. One end of each pipe was pointed, the other cut as a socket. The bark was left on to prevent decay, but in London's clay soil the pipes' useful life was only about twenty years. Although iron collars and canvas were used to strengthen the joints, probably a quarter of the water was lost in leakages (plate 2).

Subscribers to the New River water-a thousand households by 1618 - paid for two or three days' supply a week, drawn from the pipeline through branch pipes into domestic cisterns. Because of the low pressure of the flow-the elm pipes would not withstand high pressure-water could not be piped above the ground floor. ${ }^{21}$ Needless to say, opponents of the scheme drew attention to the murky quality of the water! The New River Company's pipes appear to have followed two routes from the Water House at Islington across the fields to the City, one to St John Street and the other to Goswell and Aldersgate Streets. There were no pipes in the southern part of the City (figure 2), probably because that area was served by the London Bridge and Broken Wharf (Queenhithe) waterworks. In some parishes it appears to have been a matter of prestige if one were thought suitable to have the water laid on to one's house. $^{22}$ Even some institutions did not benefit until the end of the seventeenth century.

The Company drove pipes along the Strand as far as Charing Cross before 1630. No attempt was made to supply the Covent Garden district, however, until about 1664, when there was competition from Sir Edward Forde's (later Sir Robert Vyner's) waterworks, an undertaking that had been started around 1655. These works, which pumped water from the Thames, were situated next to Somerset House and included

\footnotetext{
${ }^{20}$ Metropolitan Water Board, The water supply of London, 1961.

21 Ibid. J. W. Gough, Sir Hugh Myddleton entrepreneur and engineer, Oxford, Clarendon Press, 1964.

22 In 1595, Bevis Bulmer's own premises in Little Wood Street, St Antholin's parish, had a brass cock for conduit water laid on to the kitchen; a great lead cistern in the yard, with a pump; a waste-pipe of lead; a cock for rain-water; another long lead cistern to wash in (with 3 sections); "and a leade to pisse in with a pipe" (Guildhall Library, MS 10,344). Information supplied by G. C. Berry. In 1618, a list of the parishioners of St Michael Bassishaw was drawn up of those thought fit to have New River water. (Guildhall Library, Ward Assessment Book 1608-63, MS 3505 f.13)
} 


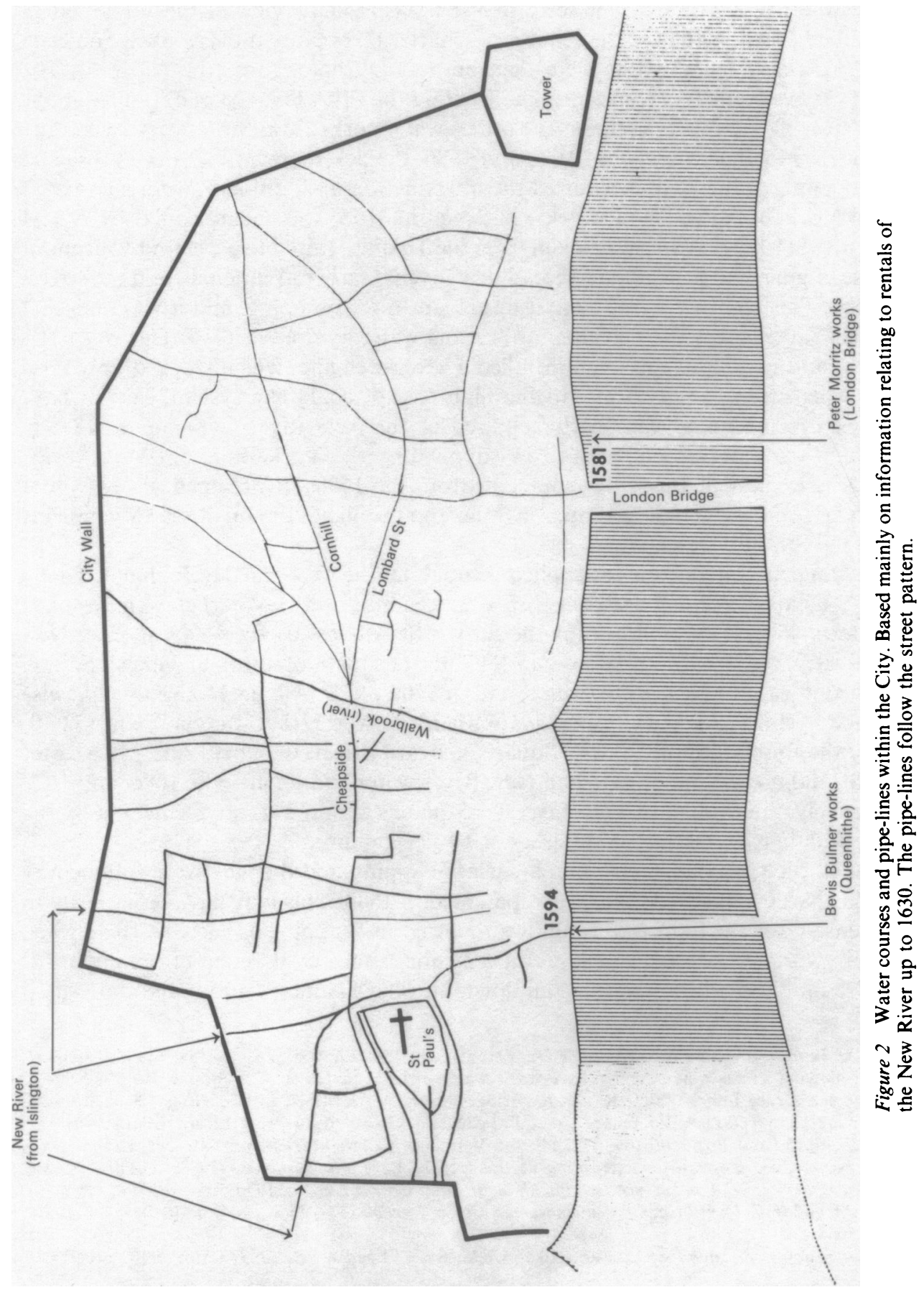




\section{Rosemary Weinstein}

a high water-tower that can be seen in Wenceslas Hollar's view of the West End. It was pulled down in 1664 at the request of Charles II, because it overlooked Somerset House (plate 3). New works were then built at Durham Yard (the Adelphi). The dispute between the two companies came before the Privy Council and resulted in the New River Company's purchase of Forde's waterworks from Sir Robert Vyner and his partners in 1667..$^{23}$ Between 1670 and 1680, the development of York House and garden south of the Strand required the introduction of additional water supplies. ${ }^{24}$

The York Buildings Waterworks, patented in 1675, was incorporated by Act of Parliament in 1691. Water was taken from the Thames, raised to a cistern by means of a horse-engine, and delivered to Piccadilly, Covent Garden, Whitehall, and the streets between. This company was the first to use steam for pumping, and it was here that Thomas Savery erected a machine for "raising water by fire" in 1712. This was not a success, and in 1726 Newcomen installed a second engine, which worked only until 1731, when it was stopped due to the high cost of coal. The system, said to have supplied 2,700 houses, was finally acquired by the New River Company in $1818^{25}$ Although Covent Garden came to be supplied by the York Building Waterworks, during its earliest phase of development, from the 1630 s, it obtained water from a variety of sources, including springs in Soho and the illicit tapping of the City pipeline along the Strand.

The same mixture of sources applied throughout the west-end development. The St James's Fields development (from $c$. 1656), Piccadilly, and Haymarket, were supplied from local springs on land held by the Earl of St Albans. By the 1690s at least, New River water was apparently laid on: in 1697, the occupant of no. 15 St James's Square obtained a lease of New River water, and in 1708 old St Albans House was likewise supplied. ${ }^{26}$ It was the York Buildings Company, however, that was chosen in 1726 to supply the fountain in St James's Square. Gerrard Street, the north side of Leicester Square, and no. 2 Soho Square had New River water laid on in 1686, 1686, and 1679 respectively, ${ }^{27}$ although in 1730 Leicester Square's supply was supplemented by the York Buildings Company, with leases at $£ 4$ per annum.

East of the City, the developing areas of Wapping and Stepney were supplied by Thomas Neale's Shadwell Company, patented in 1680. This may have been partly to compensate for the industrial pollution reported in Wapping as early as 1626, when an alum works was found to cause not only annoyance by its smell of boiling urine, but also an obnoxious scum that ran down into the Thames, tainting the water used

${ }^{23}$ G. C. Berry. Public Record Office (PRO), State Papers Domestic 1666/7 SP 29/188, nos. 156 and 157. The following streets were supplied by Forde's waterworks at that time: The Strand, Holywell Street, Wych Street, Drury Lane, White Hart Yard, Bridges Street, York Street, Charles Street, Russell Street, Bow Street, the two piazzas, Blockmore Street, Prince Street, Great Queen Street, Little Queen Street, Wild Street, Holborn Row, Portugal Row, Duke Street, Vere Street, Clare Market, and Clements Lane. Details of the New River Company's extensions at this period have not survived. (LCC, London Survey Committee, Survey of London, vol. 36: Parish of St Paul, Covent Garden, 1970, 31-2, 97.)

${ }^{24}$ W. H. and H. C. Overall (eds.), Remembrancia. City of London 1579-1664, London, 1878, 554. Letter of 8 June 1608.

${ }^{25}$ Water supply of London, op. cit., note 20 above; Survey of London, vol. 18: The Strand, London, LCC, $1937,49$.

26 Ibid., vol. 29: St James, Westminster, London, LCC, 1960, 65.

${ }^{27}$ Ibid., vol. 34: St Anne, Soho, London, GLC, 1966, 385, 461, and note p. 210. 


\section{New urban demands in early modern London}

for brewing, and poisoning the fish. The owners were ordered to move the works further away from the City and suburbs. ${ }^{28}$

The benefits of these new water supplies were gladly acknowledged by contemporaries:

with the Spring water... the New River water... and the Thames water raised by several engines or water houses, there is not a street in London, but one or other of these waters runs through it in Pipes, conveyed underground; And from those Pipes there is scarce a House, whose Rent is $£ 15$ or $£ 20$ per Annum, but hath the convenience of water brought into it.

For the small Tenements, such as are in Courts and Alleys, there is generally a Cock or Pump Common to the inhabitants so that I may boldly say, there is never a city in the world so well served with water.

(John Stow, A survey of London, 4th ed, 1633)

To those prosperous enough to have water laid on to their houses, a water lease meant simply a lead cistern, with a stopcock in the kitchen, a yard pump, and perhaps a pipe to an outside "bog house", for three to four hours' supply three days a week. However, even locals in the prosperous West End Grosvenor Estate development of 1720-85, supplied by the new Chelsea Waterworks (incorporated in 1723), (plate 4) complained that the supply was sometimes interrupted for a fortnight at a time, and as late as 1893 Mayfair, like the rest of the metropolis, did not enjoy a constant water supply. A supply on Sunday was made compulsory only in $1871 .^{29}$ The private water companies were merged under the Metropolitan Water Board in 1902.

As we have seen, attempts to control some of the metropolis's other problems, including drainage and street cleaning, had become centralized at earlier dates. In 1671, with the Sewers and Street Act (for paving and cleansing), a central drainage committee and an effective street authority were established in the City for the first time. The powers given the Commissioners (now a body representing the rate-payers and appointed by the Mayor, Aldermen, and Common Council) had powers "to impose any reasonable tax upon all houses within the said City and Liberties". Doubts that the transfer of street-cleaning duties from the individual (in the medieval tradition) to a central body, would results in delay, neglect and extravagance were unfounded. The existing parish and ward officers-scavengers, rakers, and carters, who were paid for by the "reasonable tax"-continued to be employed.

So the parish system of administration co-existed within the new municipal system. The essential difference was that, after the 1671 Act, drainage and the upkeep and cleaning of the public streets were accepted as a municipal duty throughout the City, maintained by a rate, and with representation of the rate-payers. ${ }^{30}$ Citizens no longer had to endure open gutters in the streets; pedestrians were secure from traffic as they walked along the bollard-protected pavements. The new, properly paved streets were easier to clean, the laystalls (paid for by the coal dues) at Dowgate, Puddle, and

\footnotetext{
${ }^{28}$ PRO, Calendar of State Papers Domestic 1627-87, 269; cited in Brett-James, op. cit., note 9 above, 300.

29 Survey of London, vol. 39: Mayfair, London, GLC, 1977, 30, 63.

${ }^{30}$ Brett-James, op. cit., note 9 above, 303, 4.
} 


\section{Rosemary Weinstein}

Whitefriars Docks and Mile End were adequate (although still too near the inhabitants); surplus water was carried away in drains; dangerous or offensive trades were removed from main streets, and the market system was regulated. Indeed, Dr John Woodward, lecturer in Physick at Gresham College, summed up the new City in a congratulatory letter to Christopher Wren:

... I and every Body must observe with great satisfaction, by means of the Inlargements of the streets, of the great Plenty of good water, convey'd to all Parts, of the common sewers, and other like contrivance, such Provision is made for a free Access and Passage of the Air, for sweetness, for cleanness and for salubrity that it is not only the finest, but the most healthy city in the world. ${ }^{31}$

Not until the cholera epidemic of 1831 was a stimulus to reform provided as powerful as the Plague and Fire of mid-seventeenth-century London. But such advances made by the City, spurred on by the effects of these catastrophes, must be placed in the context of the metropolis as a whole. Certainly, until the early seventeenth century, the City was ahead of the metropolis in general, but in the post-Fire period its improved standards were matched by the new housing and clean environment of the developing estates in Westminster and its outskirts.

The City's evolutionary administrative reforms in appointing a single body of commissioners with power to tax and distrain if they were not paid ("you are . . to pay ... or else your Dreyne will be stopt") were of the highest importance, and were to have a dramatic effect on the quality of life by the mid-eighteenth century. ${ }^{32}$ But by then, three-quarters of the metropolitan population lived outside the confines of the City proper. The inclination of all classes-merchants and tradesmen, as well as the rich - to move westwards away from the City accelerated after the Fire. One reason given for the loss of its inhabitants despite the post-Fire rebuilding, was "The great Inequality and Disproportion of Taxes both in Houses and Personal Estates between the City of London, and the out-Parishes of Middlesex within the Bills of Mortality". ${ }^{33}$ The new improvements had to be paid for, and inhabitants, pressed by the continuous assessments and re-assessments for this purpose, coupled with trade restrictions and liabilities, now sought the freedom of the suburbs.

\footnotetext{
31 John Woodward, letter cited in T. F. Reddaway, The rebuilding of London, London, Cape, 1940, 300.

32 Ibid., 286, 7; V. Pearl, 'Change and stability in seventeenth-century London', London J., 1979, 5: no. 1, 3-34, see pp. 26, 27.

${ }^{33}$ Guildhall Library, Broadsides 21.48. 'Reasons humbly offered to the Parliament for the abatement of the proportion of the Assessment upon The City of London', cited in Reddaway, op. cit., note 32 above, 301 .
} 


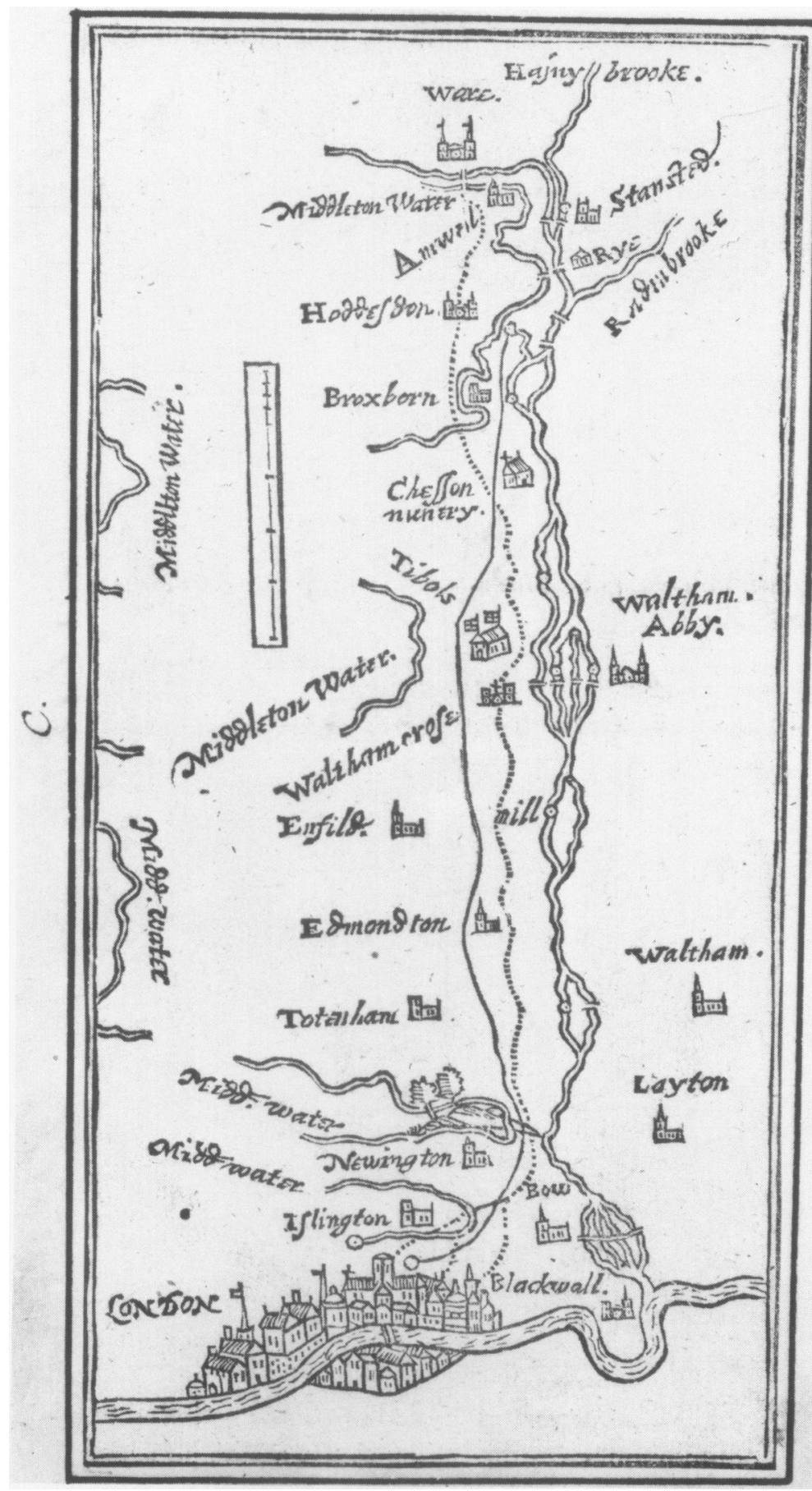

Plate 1 Woodcut map of Lea Valley showing course of Myddleton's New River from Amwell (Herts) to Islington, 1641. (Courtesy of the Master and Fellows of Magdalene College, Cambridge.) 


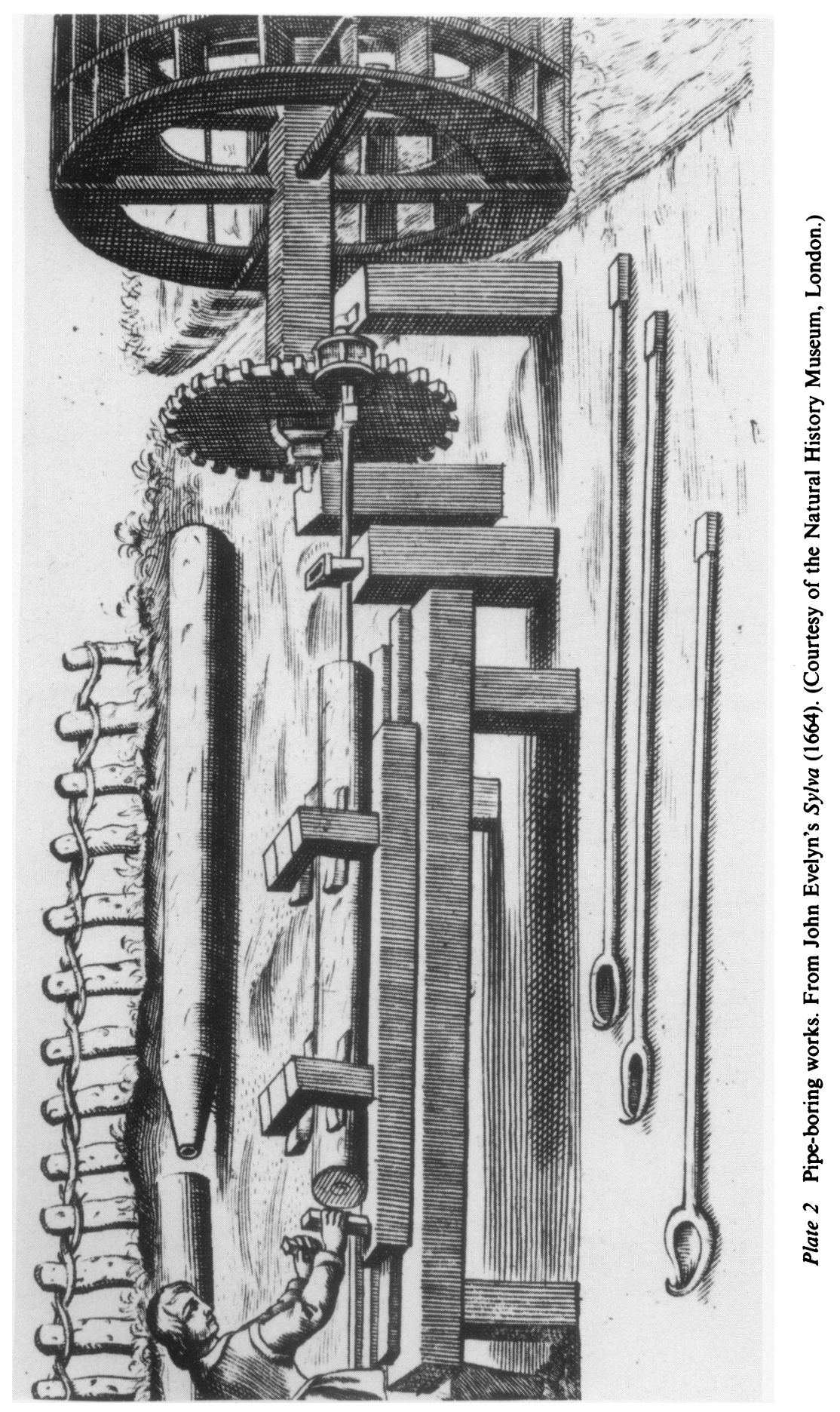




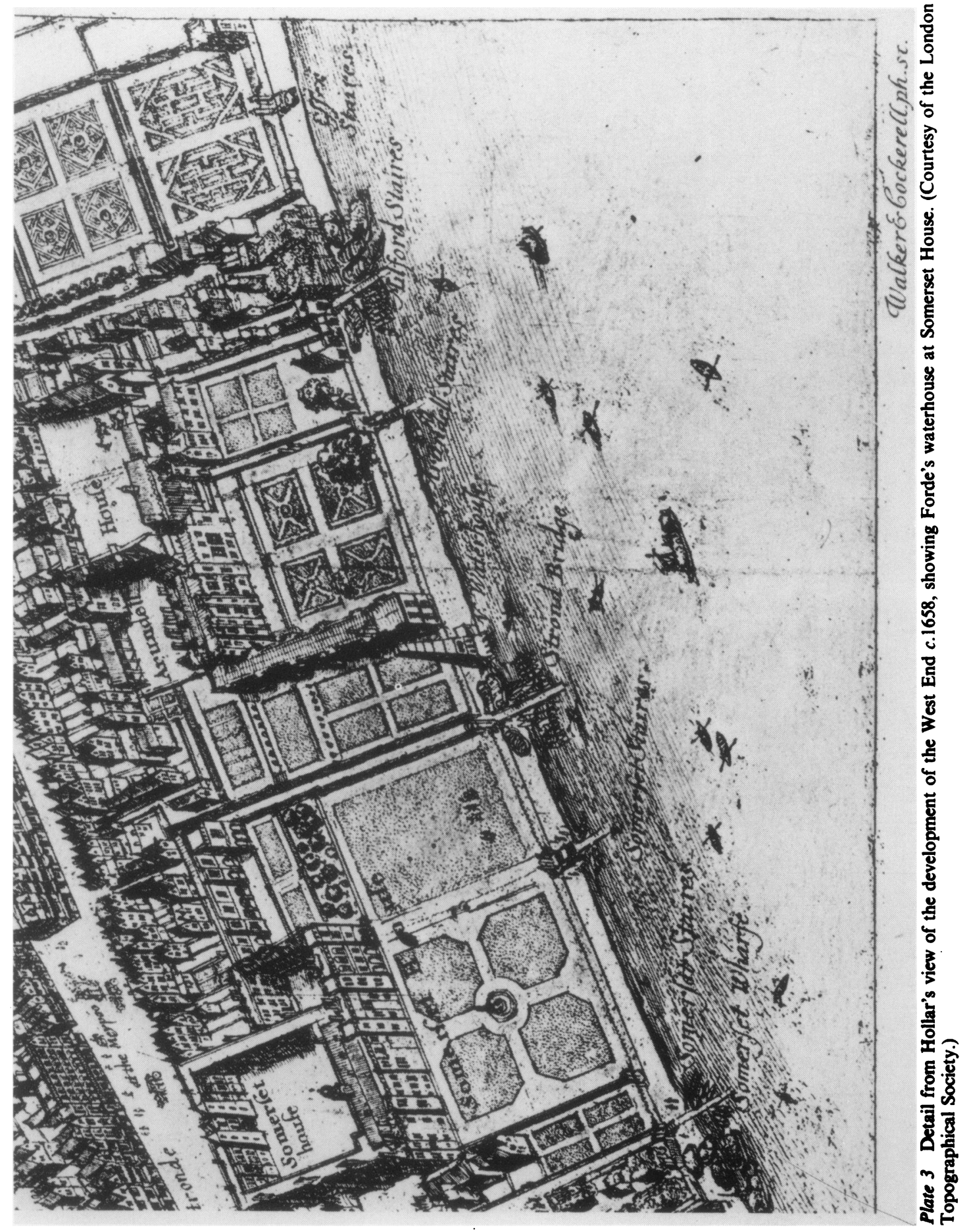




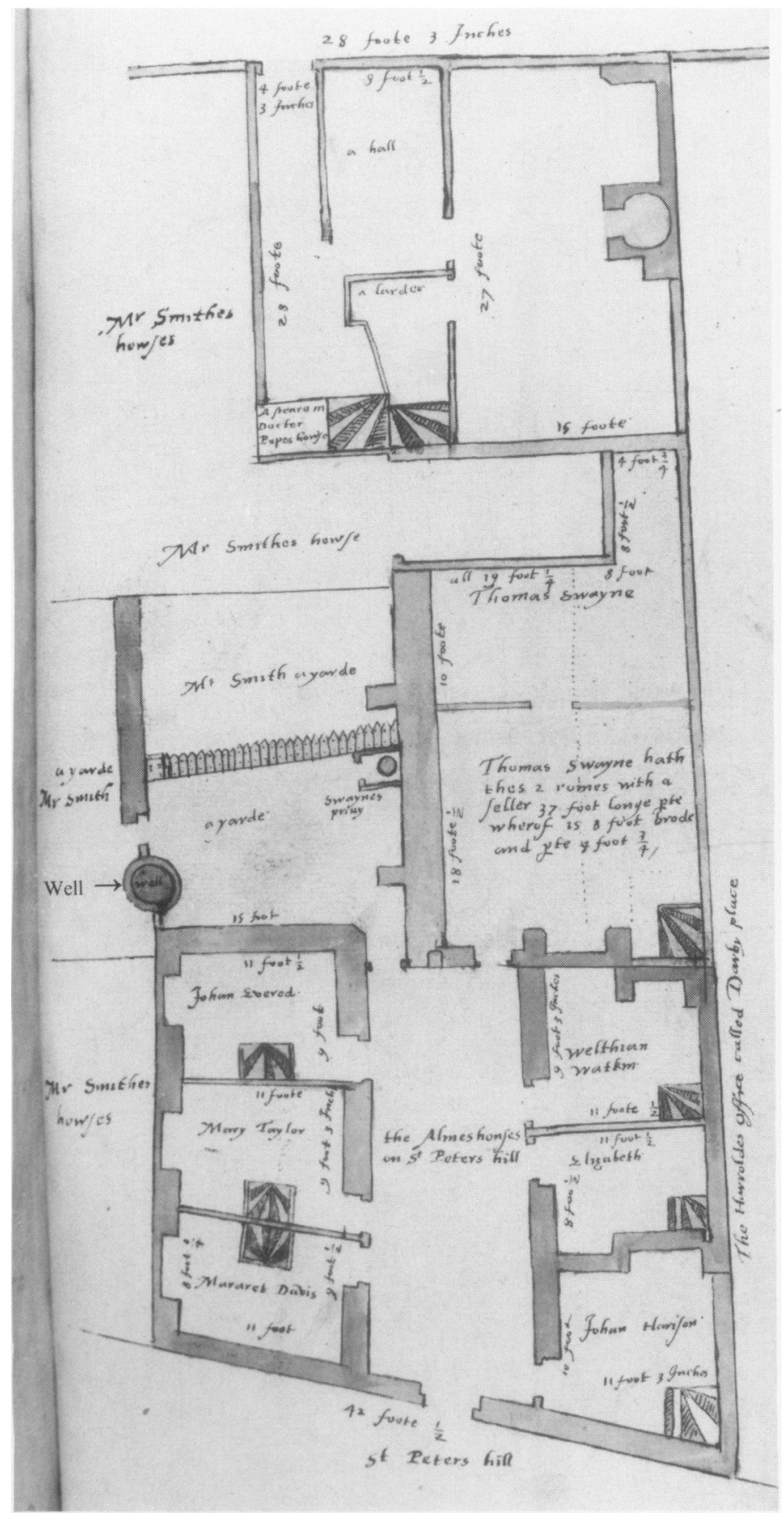

Plate 4 London survey of Smith's almshouses, St Peter's Hill (now underneath Queen Victoria Street, City of London). This survey by Ralph Treswell for Christ's Hospital in 1611 shows a common hazard: David Smith's well is only some 20 feet from Thomas Swayne's privy. (Guildhall Library MS 12805.) 